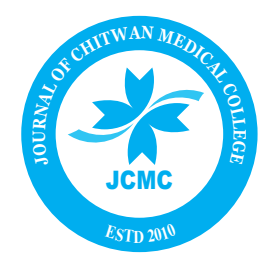

Journal of Chitwan Medical College 2019;9(28):30-35
Available online at: www.jcmc.cmc.edu.np

\title{
REPRODUCTIVE HEALTH STATUS OF MARRIED WOMEN PARTICIPATING IN CERVICAL CANCER SCREENING IN KATHMANDU
}

Ang Tshering Sherpa ${ }^{1, *}$, Neeti Singh ${ }^{2}$, Manisha Bajracharya ${ }^{3}$, Amita Pradhan $^{4}$, Peru Pradhan $^{5}$

${ }^{1}$ Department of Community Medicine, KIST Medical College and Hospital, Imadol, Lalitpur, Nepal.

${ }^{2}$ Department of Obstetrics and Gynecology, KIST Medical College and Hospital, Imadol, Lalitpur, Nepal.

${ }^{3}$ People's Dental College, Nayabazar, Kathmandu, Nepal.

${ }^{4}$ Department of Obsttrics and Gynecology, PHECT, Kirtipur

Received: 19 May, 2019

Accepted: 12 Jun, 2019

Published: 15 June, 2019

Key words: Reproductive Health; VIA.

*Correspondence to: Ang Tshering Sherpa, Department of Community Medicine, KIST Medical College and Hospital, Imadol, Lalitpur. Nepal. Email: sherpadoctor@gmail.com

DOI:http://doi.org/10.3126/jcmc.v9i2.24528

\section{Citation}

Sherpa AT, Singh N, Bajracharya M, Pradhan A, Pradhan P. Reproductive health status of married women participating in cervical cancer screening in Kathmandu. Journal of Chitwan Medical College. 2019; 9(28):30-35.

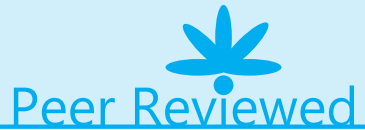

\section{INTRODUCTION}

Reproductive health is a state of complete physical, mental and social well-being and not merely the absence of disease or infirmity, in all matters relating to the reproductive system and to its functions and processes. ${ }^{1}$ International conference for population and development (ICPD) was help in Cairo Egypt, in 1994 and the conference was the turning point that sexual and reproductive health was perceived holistically and right based approach was emphasized. Though many countries have attempted to implement recommendation of Cairo conference the progress has not been satisfactory. ${ }^{2}$
Several other milestone took place for the sexual and reproductive health such as first World Health Organization (WHO) global strategy on reproductive health was endorsed by the 57.12 resolution of World Health Assembly in 2004. ${ }^{3}$ This initiated to develop and implement activities for improving sexual and reproductive health in different countries. Also 2005 world summit committed to achieve universal access to reproductive health by $2015 .{ }^{4}$ As a signatory country for Cairo Conference, Nepal government is also committed for reproductive rights for Nepalese women. Despite this, reproductive health challenges especially when it comes to adolescence marriage and adolescence pregnancy is serious problem 
in Nepal. ${ }^{5}$ Considering these problem national Adolescence sexual and reproductive health program was designed in 2011 and implemented in several districts in Nepal but not in Kathmandu. ${ }^{6}$ Therefore this study aimed to identify reproductive health status of married women in Kathmandu.

\section{METHODS}

Observational cross-sectional study was designed to use retrospective data collected during Cervical cancer screening camp conducted by KIST Medical College and Hospital (KISTMCH) at Laga Khala Clinic, Lagan, Kathmandu on 12-02- 2017. On the camp Health education regarding cervical cancer was conducted by faculties of Community Medicine, KISTMCH. Prior conducting health education Participants knowledge was assessed. Married women who give consent to have cervix examined by Visual Inspection with Acetic acid (VIA) were examined by gynecologist. VIA is the simplest cervical cancer screening method recommended for resource poor countries and that includes our part of world. ${ }^{7}$ Verbal consent was taken from Principal of KIST Medical College to use the data for study and ethical clearance was sought from Institutional review committee of KIST Medical College and Hospital.

Pilot study was done by randomly selecting (lucky draw) 10 participants from total 131 participants of camp to see the status of variables required for the study.

Sample size was calculated by taking $50 \%$ prevalence, based on prevalence of reproductive health problem among urban women in Mumbai. ${ }^{8}$ Confidence Interval $95 \%$ and $10 \%$ error of margin by using $\mathrm{N}=\mathrm{z} 2 \mathrm{P}$ q/d2 formula. Required sample size was 96 but we used 100 records.

Observational checklist was formulated based on our study objectives. Socio demographic, Reproductive health variables (Menarche, menopause, age at first marries, age at first pregnancy, number of live birth, number of pregnancy, number of abortion, cervical examination finding in relation to VIA, signs and symptoms related to reproductive health problem, knowledge about risk factors for cervical cancer, source of information and married women with ever cervix examined) were included in the study. Inclusion criteria were records with complete set of above-mentioned variables and records not torn or destroyed and written in understandable handwriting. Data entry was done and any missing data, outliers etc. were identified and corrections were made immediately. Double data entry was done to minimize the recording error. Data analysis was done descriptively using Statistical Package for social sciences (SPSS) version 20.

\section{RESULTS}

Table 1: Socio-Demographic characteristics of participants $(\mathrm{N}=100)$

\begin{tabular}{|c|c|c|}
\hline $\begin{array}{l}\text { Characteristics of } \\
\text { Participants }\end{array}$ & Frequency(N) & Percentage \\
\hline \multicolumn{3}{|l|}{ Age } \\
\hline 21 to 29 years & 21 & 21 \\
\hline $30-39$ years & 37 & 37 \\
\hline $40-49$ years & 27 & 27 \\
\hline $50-61$ years & 15 & 15 \\
\hline \multicolumn{3}{|l|}{ Ethinicity } \\
\hline $\begin{array}{l}\text { Brahmin and Chhe- } \\
\text { tri }\end{array}$ & 46 & 46 \\
\hline Newar & 28 & 28 \\
\hline $\begin{array}{l}\text { Janajati other than } \\
\text { Newar }\end{array}$ & 23 & 23 \\
\hline Dalit & 3 & 3 \\
\hline \multicolumn{3}{|l|}{ Religion } \\
\hline Hindu & 76 & 76 \\
\hline Buddhist & 17 & 17 \\
\hline Christian & 4 & 4 \\
\hline Muslim & 3 & 3 \\
\hline \multicolumn{3}{|l|}{ Level of education } \\
\hline Illiterate & 17 & 17 \\
\hline Upto Class 10 & 56 & 56 \\
\hline $\begin{array}{l}\text { SLC to bachelors } \\
\text { level }\end{array}$ & 24 & 24 \\
\hline $\begin{array}{l}\text { Masters level and } \\
\text { above }\end{array}$ & 3 & 3 \\
\hline \multicolumn{3}{|l|}{ Occupation } \\
\hline Housewife & 54 & 54 \\
\hline Daily wages & 23 & 23 \\
\hline $\begin{array}{l}\text { Small scale busi- } \\
\text { ness }\end{array}$ & 7 & 7 \\
\hline $\begin{array}{l}\text { Large scale busi- } \\
\text { ness }\end{array}$ & 14 & 14 \\
\hline Service & 2 & 2 \\
\hline
\end{tabular}

Median age at marriage was 19 years $(S D \pm 3.46)$ with minimum age 13 and maximum age 29 years. Adoles- 
cent age marries is $60 \%$ and among 91 respondents who were at-least once pregnant and 47 (51.64 \%) were pregnant at adolescent age. Among 87 respon- dents who had children, $26.43 \% 23$ (26.43\%) had 3 or more than 3 live birth children. Respondent who had at-least one abortion is 31 (31\%) (Table 2).

Table 2: Reproductive Health characteristics of participants

\begin{tabular}{|c|c|c|}
\hline Characteristics of Participants & Frequency(N) & Percentage \\
\hline $\begin{array}{l}\text { Menarche ( Median age } 13 \text { years SD } \pm 1.24 \text { ) with minimum age } 11 \\
\text { and maximum age } 17 \text { years }\end{array}$ & 100 & 100 \\
\hline $\begin{array}{l}\text { Menopause( Median age } 42 \text { years (SD } \pm 1.89 \text { ) with minimum age } 40 \\
\text { and maximum age } 47 \text { years }\end{array}$ & 20 & 20 \\
\hline $\begin{array}{l}\text { Age at marries ( Median age } 19 \text { years }(S D \pm 3.46 \text { ) with minimum age } \\
13 \text { and maximum age } 29 \text { years }\end{array}$ & 100 & 100 \\
\hline Upto 19 & 60 & 60 \\
\hline $20-24$ & 30 & 30 \\
\hline 25 and above & 10 & 10 \\
\hline $\begin{array}{l}\text { Age at First Pregnancy( Median age } 19 \text { years }(S D \pm 3.46) \text { with mini- } \\
\text { mum age } 13 \text { and maximum age } 29 \text { years }\end{array}$ & 91 & 100 \\
\hline Up to 19 years & 47 & 51.64 \\
\hline $20-24$ years & 31 & 34.06 \\
\hline 25 and above & 13 & 14.28 \\
\hline Number of live birth & 87 & 100 \\
\hline $1-2$ & 64 & 73.56 \\
\hline $3-4$ & 21 & 24.14 \\
\hline More than 4 & 02 & 2.30 \\
\hline \multicolumn{3}{|l|}{ Number of abortion $(\mathrm{N}=100)$} \\
\hline No abortion & 69 & 69 \\
\hline 1-2 abortions & 23 & 23 \\
\hline More than 2 abortions & 08 & 08 \\
\hline
\end{tabular}

Table 3: Reproductive Health problem reported by respondents

\begin{tabular}{|l|c|c|}
\hline \multicolumn{1}{|c|}{ Characteristics Reproductive Health problem } & Frequency(N) & Percentage \\
\hline Lower Abdominal pain & 59 & 59 \\
\hline Yes & 41 & 41 \\
\hline No & 53 & 53 \\
\hline Vaginal discharge and or itchiness & 47 \\
\hline Yes & \multicolumn{2}{|c|}{} \\
\hline No & 08 & 08 \\
\hline Genital Ulcer & 92 & 92 \\
\hline Yes & 21 & 21 \\
\hline No & 79 & 79 \\
\hline Wart(cowliflower like growth in genital area and or periphery skin) & \\
\hline Yes & 21 \\
\hline No & 79 \\
\hline
\end{tabular}


Among sign and symptoms of reproductive health problem lower abdominal pain and vaginal discharge and or itchiness were the most common. Symptoms of reproductive health problem reported were lower abdominal pain was 59(59\%), vaginal discharge and or itchiness $53(53 \%)$, wart like growth 21 (21\%) and genital ulcer 8(8\%) (Table 3).

Cervical examination in relation with visual inspection with acetic acid (VIA) showed 3 (3\%) VIA positive, 33(33\%) Cervicitis,10(10\%) cervical polyp, $7(7 \%)$ atrophic vaginitis, $4(4 \%)$ cervical erosion and 43(43\%) healthy cervix (Table 4).

Table 4: Cervical Exam Clinical Findings in relation with Visual Inspection with acetic acid (VIA)

\begin{tabular}{|l|c|c|}
\hline & Frequency & Percentage \\
\hline Cervicitis & 33 & 33 \\
\hline Cervical polyp & 10 & 10 \\
\hline Atrophic Vaginitis & 7 & 7 \\
\hline Cervical Erosion & 4 & 4 \\
\hline VIA positive & 3 & 3 \\
\hline Healthy Cervix & 43 & 43 \\
\hline Total & 100 & 100 \\
\hline
\end{tabular}

Majority of respondents with sign and symptoms of reproductive health problem and cervical anomalies, only $46(46 \%)$ had their cervix examined at le ast once. Respondent's knowledge of cervical cancer risk factors are also unsatisfactory as only 8 (8\%) had very good knowledge and $74(74 \%)$ with some extent of knowledge and 18 (18\%) had no knowledge (Table 5).

Table 5: Respondent's knowledge of cervical cancer risk factors

\begin{tabular}{|l|c|c|}
\hline & Frequency & Percentage \\
\hline $\begin{array}{l}\text { Very good knowl- } \\
\text { edge of risk factors } \\
\text { for cervical cancer }\end{array}$ & 8 & 8 \\
\hline $\begin{array}{l}\text { Some extent of } \\
\text { knowledge of risk } \\
\text { factors for cervical } \\
\text { cancer }\end{array}$ & 74 & 74 \\
\hline $\begin{array}{l}\text { No knowledge of } \\
\text { risk factors for cervi- } \\
\text { cal cancer }\end{array}$ & 18 & 18 \\
\hline Total & $\mathbf{1 0 0}$ & $\mathbf{1 0 0}$ \\
\hline
\end{tabular}

Among 46 who have heard about cervical cancer, Source of information about cervical cancer risk factors of respondents are mostly from social network like friend and families 16(34.7\%), radio and or television $12(26.08 \%)$, social media $10(21.7 \%)$ and only 8 (17.39) from Health worker (Table 6).

Table 6: Source of Information about cervical cancer risk factors $(\mathrm{N}=46)$

\begin{tabular}{|l|c|c|}
\hline & Frequency & Percentage \\
\hline $\begin{array}{l}\text { Social Networks } \\
\text { (Friends and Families) }\end{array}$ & 16 & 34.7 \\
\hline $\begin{array}{l}\text { Social Media (Face- } \\
\text { book, Google, Insta- } \\
\text { gram etc) }\end{array}$ & 10 & 21.7 \\
\hline Television/Radio & 12 & 26.08 \\
\hline Health Worker & 08 & 17.39 \\
\hline Total & 46 & 100 \\
\hline
\end{tabular}

\section{DISCUSSION}

Our study participants are presently residing at Kathmandu with age group of 21 to 61 years old. Eighty-three (83) \% of them were literate. This finding was little higher than $75.19 \%$ female literacy rate among urban population according national population and housing census, 2011. ${ }^{9}$ Statistical Trends in Literacy Rates in Nepal done by Basanta Dhakal in 2018 showed that literacy rate is in increasing trend. ${ }^{10}$ This confirms our finding.

Ethnicity wise 74 (74\%) of participants were Brahmin, Chhetri and Newar. Study done by Bennett Lynn et al.on Caste and ethnicity of Nepal in 2006 showed that they were the main ethnic group in Kathmandu valley and majority of them are Hindu. ${ }^{11}$ We also found $76 \%$ of our participants are Hindu. Considering socio demographic pattern of our study participant, they represent women inhabitant of Kathmandu and hilly area.

In our study median age at marriage was 19 years, which is below than legal age for marriage. Legal age for marriage in Nepal is 20 is for both girls and boys. ${ }^{12}$ However, with parental consent they can marry at the age of 18 . Our study found $60 \%$ (60) adolescence marriage. This showed either adolescent marriage is parents will or the implementation 
of law is poor in Nepal. Our study also showed high adolescent pregnancy $47(51.64 \%)$, participants with 3 or more than 3 live birth children 23 (26.43\%) and at-least one abortion 31 (31\%). However, we have not sought the cause of reproductive health problem but other study has shown unmet reproductive health problem in Nepal is high. ${ }^{13}$ This may also apply for our case. So further research should be needed. When asked for number of pregnancies among participants 9 (9\%) were never got pregnant. This may be due to infertility. This is similar with study done by Dangal G, on reproductive morbidity in Eastern Nepal. ${ }^{14}$

Regarding Symptoms suggestive of reproductive health problem lower abdominal pain and vaginal discharge and or itchiness were the most common. Fifty-nine (59\%) agreed to have experienced lower abdominal pain, 53(53\%) vaginal discharge and or itchiness, 21 (21\%) wart like growth and 8(8\%) genital ulcer). This finding is similar with community based study conducted in Rupandehi, Nepal. ${ }^{15}$

Cervical examination in relation with visual inspection with acetic acid (VIA) showed 53 (53\%) had unhealthy cervix. Among them cervicitis was the most common. It is proven fact that the main cause of cervicitis is sexually transmitted infections and most often they are asymptomatic and if lead untreated it may lead reproductive morbidities.

Three (3) \% of the participants were found VIA positive this indicates 3 of them may have precancerous lesions. Cancer mortality profile among female in Nepal showed that cervical cancer is the most common accounting $18.4 \%$ of all cancer. ${ }^{16}$ Wart like growth in genital a is caused by Human Papilloma virus (HPV) and our study showed $21 \%$ had this problem. It is proven that High risk HPV is the main causative factors for causing cervical cancer. Our own study showed that HPV 16 and 18 is the HPV strain associated with cervical cancer. ${ }^{17}$

Significant number of women had symptoms of reproductive health problem, cervicitis and wart like growth but only $46 \%$ (46) had their cervix examined at least once. Low rate of cervical cancer screening among women in Nepal is also shown by other study conducted in Nepal. ${ }^{18}$ Such kind of trend may lead negative impact on reproductive health of women in Nepal. So in depth study regarding the cause of women not having cervical examination must be carried out and intervention should be targeted to it to prevent morbidity and mortality related to it. Participant's knowledge of cervical cancer risk factors were also found unsatisfactory as only $8 \%$ (8) had very good knowledge and $74 \%$ (74) with some extent of knowledge and $18 \%$ (18) had no knowledge. This finding is supported by other study conducted in Nepal. ${ }^{19}$

Majority of participant's source of information was from social network like friends and families Participant's source of information about cervical cancer risk factors are mostly from social network like friend and families 16(34.7\%) and very few got information through health worker 8 (17.39\%). This indicated that participants may not have got correct information and if this was the reality, reproductive right of women to get proper information may be jeopardized.

\section{CONCLUSIONS}

Adolescent marriage, pregnancy at adolescence age, reproductive health problems are the main problem noted among married women in Kathmandu. Despite having significant number of women with reproductive problems only few were noted having cervical examination done. Also, role of health worker in information dissemination was found very low. All of these factors may contribute poor reproductive health. So intervention should be targeted in these issues.

\section{ACKNOWLEDGEMENT}

The authors would like to thank all the participants, KIST Medical college management and Laga Khala Club. Without their support this study cannot be accomplished.

\section{REFERENCES}

1. United Nations Populations Fund (UNFPA) Guidelines on Reproductive Health. Available at: https://www.un.org/popin/unfpa/taskforce/ guide/iatfreph.gdl.html. Accessed Jun 9, 2019

2. Population Reference Bureau. What was Cairo? The promise and reality of ICPD. Sep142004 https://www.prb.org/ whatwascairothepromiseandrealityoficpd/. Accessed Jun9, 2019 
3. World Health Organaization. World Health Assembly adopts forst global health strategy on reproductive health and resolution of family and health. https://www.who.int/mediacentre/ news/releases/2004/wha2/en/

Accessed Jun9,2019

4. United Nations Populations Fund (UNFPA) World Summit Commit to Universal Access to Reproductive Health by 2015. 19 Sep 2005. https://www.unfpa.org/press/world-summitcommits-universal-access-reproductivehealth-2015 Accessed Jun9, 2019

5. Nepal S, Atreya A, Kanchhan T. Teenage pregnancies in Nepal-The problem status and socio-legal concerns. Nepal Medical Assoc2018;56(211):678-82

6. Ministry of Health, Government of Nepal. Annual Report. Department of Health services 2015/16. http://www.dohs.gov.np/ wpcontent/uploads/2017/06/DoHS_Annual_ Report_2072_73.pdf Accessed Jun9,2019

7. Sankaranarayanan, R, Shyamalakumary, B, Wesley, R, Sreedevi Amma, N, Parkin, DM, Nair, MK. Visual inspection with acetic acid in the early detection of cervical cancer and precursors[letter]. Int J Cancer 1999; 80( 1): 1613.

8. SogarwalR, .Gupta K, DwivediL.K. REPRODUCTIVE HEALTH PROBLEMS AMONG URBAN WOMEN: A STUDY OF FOUR METRO CITIES IN INDIA. Health and Population Perspectives and Issues 29(3): 116-128, 2006.

9. Central Bureau of Statistics Kathmandu Nepal Nov 2012 Gov. of Nepal. National Population and housing census 2011. https://nepal.unfpa.org/ sites/default/files/pub-pdf/Nepal-Census-2011Vol1.pdf Accessed Jun92019

10. Dhakal B. Statistical Trends in Literacy rate in Nepal. IOSR Journal of Applied Chemistry 2018; 11(11): 71-77

11. Bennett, Lynn, Dilli Ram Dahal and Pav Govindasamy, 2008. Caste, Ethnic and Regional
Identity in Nepal: Further Analysis of the 2006 Nepal Demographic and Health Survey. Calverton, Maryland, USA: Macro International Inc.

12. The Himalayan Times. Minimum age for marriage being upgraded to 20.Dec 242016 . https:// thehimalayantimes.com/nepal/minimum-agefor-marriage-being-upgraded-to-20/ Accessed Jun92019

13. Malqvist $M$, Hulstrand J,Larsson $M, K C$ A. High levels of unmet need of family planning in Nepal. Sexual and Reproductive Health Care.2018;17:16

14. Dangal, G. . A study of reproductive morbidity of women in the Eastern Terai Region of Nepal. Nepal Journal of Obstetrics and Gynaecology, 3(1), 29-34.

15. KaphleP, Bhattarai S S. Prevalence and factor associated with reproductive tract infections in Gangolia village,Rupandehi District, Nepal. Advances in Public Health. 2016 http://dx.doi. org/10.1155/2016/8063843

16. WorldHealth Organization-Cancer Country Profiles, 2014. https://www.who.int/cancer/ country-profiles/npl_en.pdf Accessed Jun9,2019

17. Sherpa AT, Clifford GM, Vaccarella S, Shrestha S, Nygard M, Karki BS, et al. Human papillomavirus infection in women with and without cervical cancer in Nepal. Cancer causes \& control: CCC. 2010 Mar; 21(3):323-30.

18. Ranjit A,Gupta S,Shrestha R,Kushner AL,Nwomeh $\mathrm{BC}$, Groen RS.Awareness and prevalence of cervical cancer screening among women in Nepal. International journal of gynecology and obstetrics.2016; 134 (1):37-40

19. Thapa N. et al. Knowledge, attitude, practice and barriers of cervical cancer screening among women living in mid-western rural, Nepal. J Gynecol Oncol 2018 Jul;29 (4) 